\title{
The Costs and Inference of the Non Electric Affairs in the Electricity Sector: The Political Costs
}

\author{
Nuno Domingues (Corresponding author) \\ ISEL-ADEM \\ Rua Conselheiro Emídio Navarro, 1, 1959-007 Lisboa, Portugal \\ E-mail: nndomingues@gmail.com
}

Received: May 2, 2018 Accepted: May 22, 2018 Published: May 29, 2018

doi:10.5296/csbm.v5i1.13215 URL: http://dx.doi.org/10.5296/csbm.v5i1.13215

\begin{abstract}
Due to the public acceptance and to the elections, governants decide to support ways to keep the energy prices low and to avoid major price increases. This could lead to the wrong sensation of a cheap energy and avoid attention from energy efficiency investments and energy savings. This paper compares the actual Portuguese system and the same system without the designated Political Costs.
\end{abstract}

Keywords: political costs, tariffs, electricity prices, electricity costs 


\section{Macrothink \\ Case Studies in Business and Management \\ ISSN 2333-3324 \\ 2018, Vol. 5, No. 1}

\section{Introduction}

The political costs of electricity in Portugal in 2010, designated to be paid in the following 15 years, are illustrated in Table 1.

Table 1. Political costs of electricity in Portugal in 2010

\begin{tabular}{lc}
\hline Political Costs of Electricity & $\mathbf{( 1 0}^{\mathbf{3}}$ Euro $)$ \\
\hline Total & 1826309 \\
PRE & 805123 \\
CAE & 248060 \\
CMEC & 305026 \\
CIEG & 37036 \\
Interests for tariffs deficit & 20026 \\
(BT-2006 and BTN- 2007) & \\
PPDA & 18211 \\
PPEC & 11500 \\
\hline
\end{tabular}

By 2007, previously of operating in a free market, were established price contracts with electricity generators, called Power Purchase Agreements (Contratos de Aquisição de Energia- CAE), paying for the electricity production. The CAE guaranteed the recovery of the production fixed costs. The volatility of fuel prices affect the variable costs, so that the annual estimates of these differences may exist, causing extra costs or surplus situations, if they are inferior or superior to that observed, respectively. The difference between the forecast and observed is, in principle, corrected the following year. With this contract still remains Tejo Energia (Central Pego) and Turbogás (Central Tapada Outeiro), managed by REN Trading. The REN must resell the electricity of these two CAE and pay the energy costs defined in the respective CAE. The difference between costs and revenues is recovered through the rate applied by UGS.

The amount in respect CMEC is integrated in Tariff Global Use of System and consists of a fixed portion and a portion of a hit, which is published by ERSE. The establishment of CMEC is based on calculating the difference between the present values of expected revenues for a certain power-generating plant, prior to the liberalization of markets, as set out in the CAE. The factors that introduce adjustments of CMEC are the following:

- Price of energy versus electric revenue generator.

- Production of the plants versus generator net cost. 


\section{Macrothink \\ Case Studies in Business and Management \\ ISSN 2333-3324 \\ 2018, Vol. 5, No. 1}

- Evolution of operating costs (fuel costs and allowances CO2).

- Availability of the central factor that increases the cost of power.

- Evolution of the inflation rate, a factor that increases the cost of power.

\section{Simulation}

The scenarios simulated were the following presented in Table 2.

Table 2. Scenarios simulated

\begin{tabular}{ll}
\hline Scenario 1 & BAU with all costs and tariff parcels \\
\hline Scenario 2 & BAU without political costs \\
\hline
\end{tabular}

All the scenarios are for the period 2010-2024 and assuming all non dispatchable technologies produce at the average (capability index $=1$ ).

The simulations can provide answer to the following questions:

- Who will invest in what?

- What is the real environmental effectiveness of energy efficiency measures?

- How to communicate to an ordinary citizen?

- What are the economic sectors and/or agents which is more cost-effective to guide?

- What are the costs of meeting mitigation targets or the carbon price?

- How do technology and fuel mix changes from energy and/or policies affect energy prices?

From Figure 1 until Figure 2 it is illustrated the total costs, the revenues and the economic balance for all scenarios. 


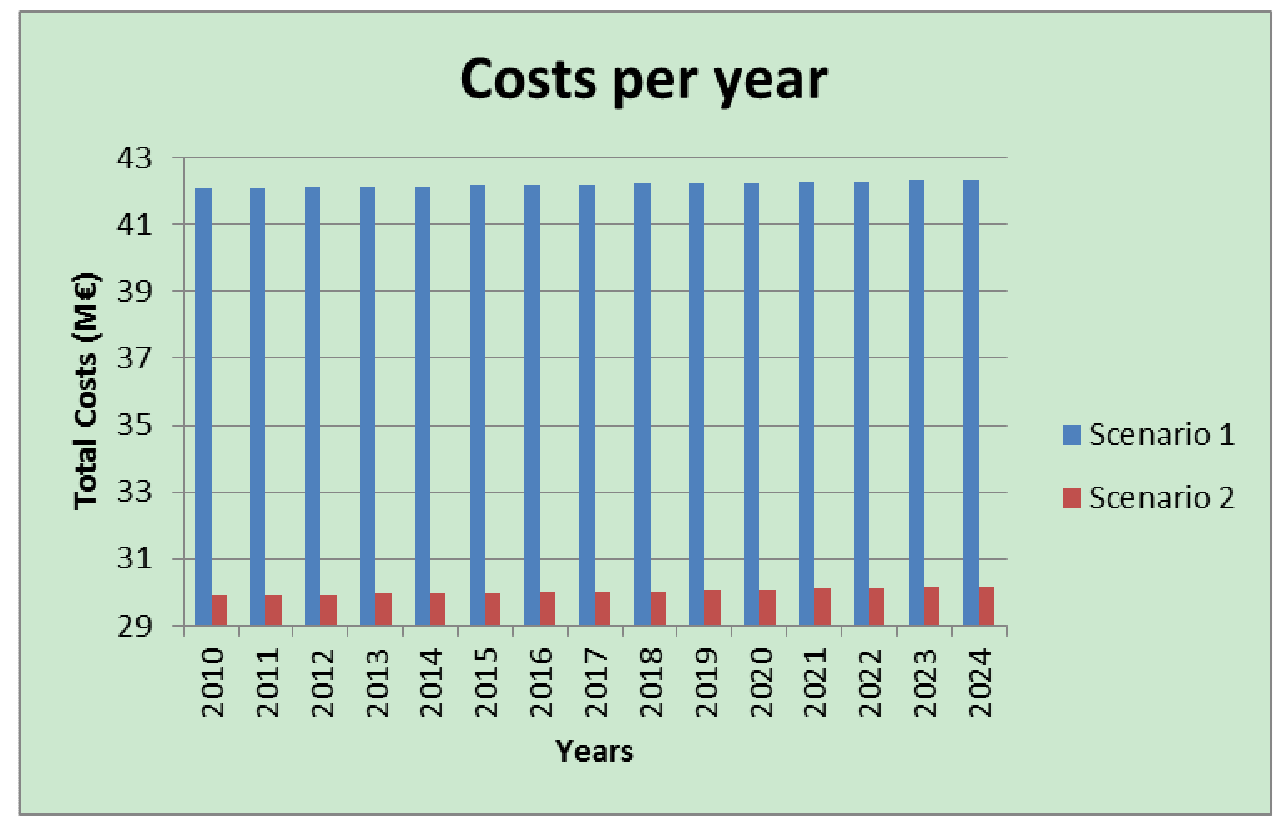

Figure 1. Total costs per year for scenario 1 and scenario 2

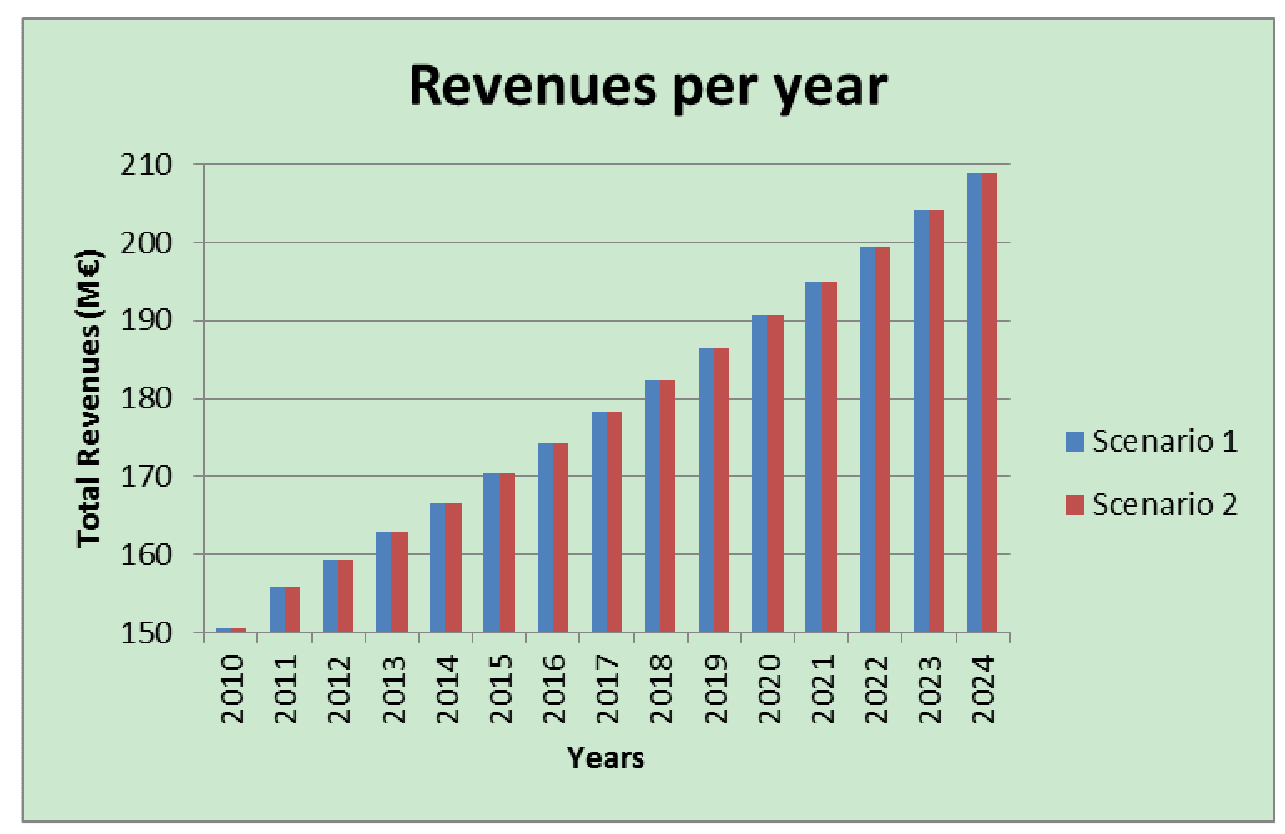

Figure 2. Revenues per year for scenario 1 and scenario 2 


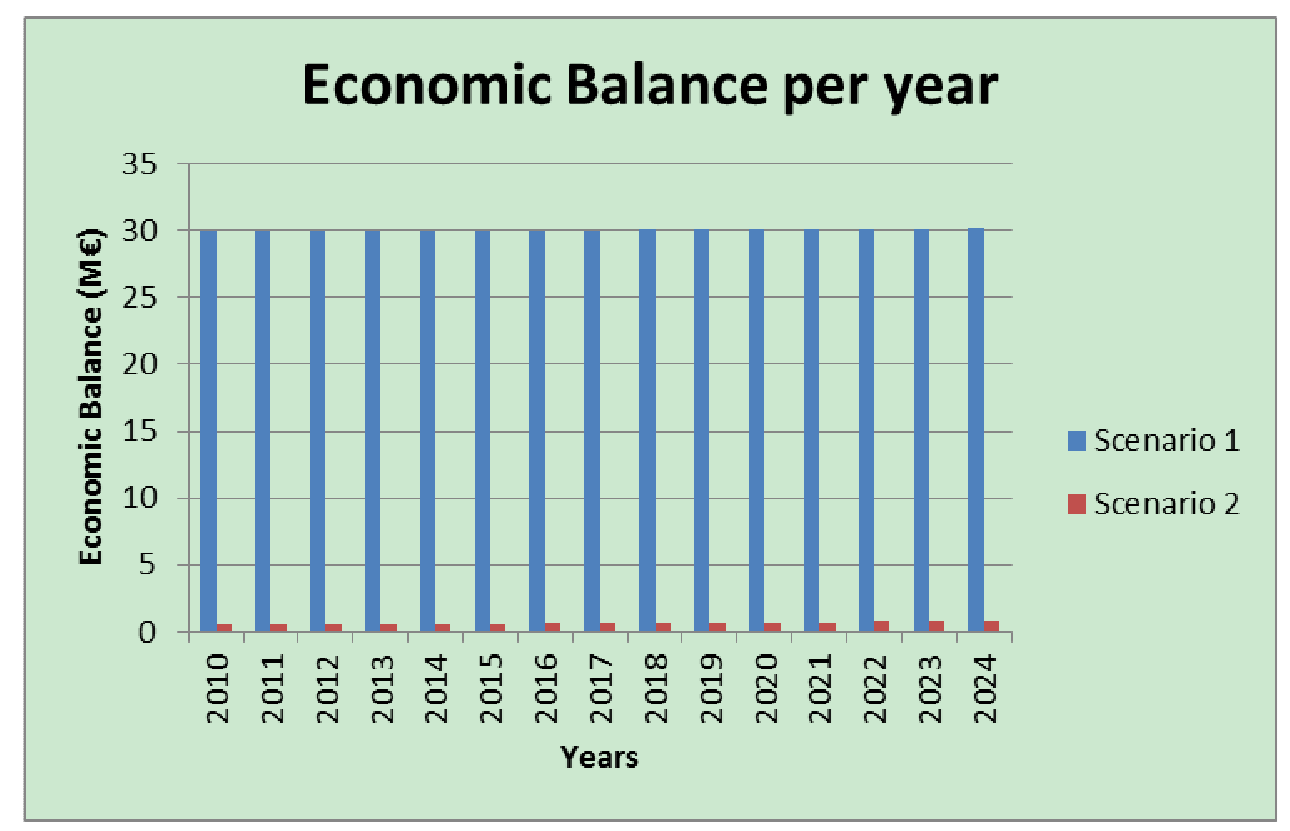

Figure 3. Economic Balance per year for scenario 1 and scenario 2

Comparing scenario 1 to scenario 2, it is obvious the economical impact of external items, like the political costs. These costs were introduced to the electric system for different reasons, starting from innovation, going through continuity of supply and ending on misleading social/ industry protection. After all, these are merely market-distorting and exemptions that should be place away as soon as possible to create a suitable internal electricity market in the European Union, as indicated in the three liberalisation packages (Note 1). Even with these external items, like the political costs, there is still enough «money in the pot». However, taking this money for the wrong proposes is a distraction from the important investments. Another problem is that a huge parcel of these costs is subsidising polluting technologies. More than that, part of it where due to artificial low prices, misleading the consumers on the efficient use of electricity. Based on these two first scenarios, one can conclude that Portugal is not taxing too much, but is taxing wrong. The next simulations illustrate some examples on investments in energy efficiency that can be done with this money and will lead to a better environmental protection.

\section{Conclusions}

Political and legal decisions determine the framework conditions for energy markets and are intended to influence development of energy production and energy use (Note 2).

In the model, the technological or behavioural energetically less efficient and /or more carbon-intensive is taken in consideration. That way, the change considered is not only on the behaviour or primary energy but also on the substitution of technologies, while maintaining their activities (production and labour, on one hand, and levels of comfort and welfare, on the other hand). For that one should need to determine what is the appropriate and the minimal consumption in order to identify and penalize unnecessary consumption. 


\section{Macrothink \\ Case Studies in Business and Management \\ ISSN 2333-3324 \\ 2018, Vol. 5, No. 1}

\section{Future Developments}

The model is prepared for substantial increases in complexity. The input data for the model can be easily found in reports or defined by outputs of other models. However, the user should be aware that it is common to find different values for the same item, even in trustful agencies or entities.

Considering the scope and the knowledge involved, any future development that focus on the future electricity business model questions can be made on consequence of the study of the present thesis, namely:

○ What are the most competitive technologies?

- What behaviour consumers have to have?

- What is the effect of energy or environment policy instruments?

- What might define the future?

$\circ$ What will remain?

○ Which structural limitations there are?

○ What can project Portugal?

- What is the weight of science on decision making in society?

On future developments, one should focus on potential uncertainties for future, namely:

- capacity of innovation and investment in $R \& D$

○ quality, efficiency and evolution of the energy systems

○ attractiveness of other solutions

- strategic vision and quality of governance

$\bigcirc$ evolution of the Portuguese economy

○ the role of Portugal in the global economy

○ financial sustainability of the Portuguese economy

○ external imbalances

- national debt and private debt

$\bigcirc$ political system model

- redistributive mechanisms

○ labour market

○ evolution and credibility of the institutions

$\circ$ individual benefit and collective benefit 
○ typology and role of the cities in spatial planning

$\circ$ cultural values and cultural changes

$\bigcirc$ intensity and impacts aging of the population in Portugal

The analysis should be dynamic: at the same time as the measures are efficiently introduced, the overall efficiency objective will be near and the revenues will decrease over time. Measures serve two purposes: to change behaviour and to raise money for the government. To ensure preservation of both, the measure should be tuned or applied on another focus.

To compare the output data of the simulator to the ordinary published data, one can index the price of coal and the price of natural gas to the price of oil and calculate the desired output data. It is not done yet because that approach could magnify the importance of oil in the electric system.

The building sector is responsible for a large share of electricity consumption and raw materials use. In 2010 in Portugal there are 2560911 buildings constructed before 1990 (year of publication of the $1^{\text {st }}$ regulation on energy performance of buildings) representing $76.6 \%$ of the existing buildings. Due to lack of thermal requirements and concerns, they present themselves as highly energy consuming when on minimum comfort conditions requirements.

Energy efficiency is not as popular and soundy as renewable energy production, but it is an even bigger success story because of immediate impact on the bottom-line, the long term effect and the contagious effect. The introduction of renewable energy has had no appreciable effect in reducing the external debt and has exacerbated the tariff deficit (impacts that consumers and/or taxpayers will have to pay). In Portugal, investment in renewable energy have the risk of being too gigantic (e.g., large scale solar plants) having serious strongly conflicts with the environment (e.g., dams for hydro power) or becoming less profitable (e.g., the windy areas are less available). Investing in energy efficiency is often said to be far cheaper than expanding the energy supply to meet growing demand. The present model can introduce some light on the debate. Some thoughts on this are:

- A greater amount of wind generation avoids fuel expenses but still requires investments in backup capacity. The necessary backup capacity could be provided by new flexible generation plants, by extend the lifetime of existing ones, increasing interconnection capacity (in order to "import" backup capacity from abroad), developing energy storage facilities (e.g. pump storage, district heating systems, electric vehicles, flying wheels, etc.);

- Earth has a limited amount of water that recycles itself in what is called the 'water cycle'. A rapidly growing environmental dilemma is behind the dam proliferation: the nutrient over enrichment of freshwater and coastal ecosystems (or eutrophication), leading to dead zones in coastal areas. Stronger relations and impacts of hydropower should be done. The present model can input them and output indicators to analyse the internalization of this costs to environment and society. 
A low carbon future requires a physical low carbon infrastructure: a smart grid. Existing electricity grids are typically a mix of local grids that are simultaneously inefficient (with $10 \%$ losses and self consumption) and dysfunctional (they often are unable, for example, to move electricity surpluses to areas of shortages or to move low-cost electricity to consumers because of congestion on transmission lines). A smart grid not only moves electricity more efficiently in geographic terms; it also enables electricity use to be shifted over time-for example, from periods of peak demand to those of off-peak demand. Smart grids allow electricity to flow bi-directional and enable a parallel flow of information.

Market-based decisions in liberalised markets are not technology-neutral. They favour short-term profits and that encourages the building of power plants with low capital costs and high marginal costs. In the absence of incentives, that means gas-fired plants, which make profit whether the spot price is high or low. Defining the technology-based incentives could downgrade this advantage.

Assuming fossil fuels will continue to have a primary role for electricity generation in future, the implementation of pollution mitigation and Carbon Capture and Store (CCS) technologies should be evaluated. The CCS technology is pointed as a path to continue to burn fossil fuel but without environmental pollution. However, for CCS it's needed about 30\% more energy and a tank reservoir of $2 \mathrm{~m}^{3}$ for each tonne of carbon. The model is fully ready for this study.

More and more utilities are beginning to realize that building large power plants just to handle peak daily and seasonal demand is a very costly way of managing an electricity system. This is one of the reasons that production sector agents apply for efficiency use of energy. The model is not yet prepared for intraday measures and behaviours but as a raw approach on the subject, represented by the load factor.

Portugal is currently assisting an increasing electrification process, turning electricity into the biggest energy consumed. The most recent sector to do it is going to be the mobility and transport. The economic uncertainty, oil insecurity, rising gasoline prices, mounting concerns about climate change and a declining interest in cars among young people could be a step to increase the public transportation users and reduce the private cars. But the individual and company transports shift from fossil fuel to electricity (small scale or massification (Note 3)) impacts in the electric system of electric vehicles is felt intraday, in the load diagram, and should be quantified.

Along with the impacts of measures evaluation, one can on how to redistribute the revenues of the tax by earmarking. There are a number of possibilities (that can be combined) for using the revenue that governments raise through EFR, which can be studied:

- it could be retain by the government, add it to other government revenue streams within the general budget, reducing the deficit, contributing to a budget surplus and allowing the use of revenues through time

- it could be used to pay for additional public spending (health, education and public transport) or earmarked for a special fund that are set aside for a specific project 
- it could be used to reimburse or to relieve the costs for the distributive impact of the taxation or pricing measure

- it could be used to compensate those who suffer from pollution or resource depletion.

- it could be used to reimburse the most negatively affected industries

- it could be used to replacing (partially or wholly) existing taxes (such as labour and family budget) or social security contributions.

Some future developments are more challenging to do with the present model, such as:

- - The exponential increase in energy costs and the high value of the energy bill that citizens have to pay makes all issues related to energy and energy efficiency have become of dominant importance for society. What is the role of mass media?

- - Public private partnership (PPP) is a form of project financing, wherein a private entity receives a concession from the private or public sector to finance, design, construct, and operate a facility stated in the concession fixed term. This enables the project proponent to recover its capital, operating and maintenance expenses in the project. Due to the long-term nature of the arrangement, the fees are usually raised during the concession period. The rate of increase is often tied to a combination of internal and external variables, allowing the proponent to reach a satisfactory internal rate of return for its capital. PPP in infrastructure concerns a "long-term fixed arrangement between a public sector agency and a private sector concern, whereby resources and uncertainties are shared for the purpose of developing or refurbishing a public facility.

- - Regarding demography, it was considered the evolution of the number of inhabitants, but aging of the population can also play a role of the amount and the time of consumption. The demographic structure of most developed countries is changing dramatically as a result of people living longer but having fewer children. These demographic changes request energy services that pose more challenges for sustainable development. It takes many years for countries and regions to change their infrastructure, housing, transport, energy and water systems. Models for the sustainable development of energy, cities, water, and natural resources have not, as yet, explicitly accommodated changing demographics. The present model also has this lack.

\section{References}

DECO- defesa dos direitos do consumidor, Eletricidade e gás- Compare tarifas de eletricidade e gás natural. Retrieved from https://www.deco.proteste.pt/

ERSE- Entidade Reguladora dos Serviços Energéticos, Diretiva n. ${ }^{\circ}$ 2/2017 - Tarifas e preços para a energia elétrica e outros serviços em 2018, December 2017

ERSE- Entidade Reguladora dos Serviços Energéticos, Estrutura Tarifária do Setor Elétrico em 2018, December 2017

ERSE- Entidade Reguladora dos Serviços Energéticos, Proveitos permitidos e ajustamentos 


\section{Macrothink \\ Case Studies in Business and Management \\ ISSN 2333-3324 \\ 2018, Vol. 5, No. 1}

para 2018 das empresas reguladas do setor elétrico, December 2017

REN - Redes Energéticas Nacionais, Facts and figures. Retrieved from http://www.ren.pt/pt-PT/quem_somos/facts_and_figures/

REN - Redes Energéticas Nacionais, Information centre. Retrieved from http://www.centrodeinformacao.ren.pt/PT/Paginas/CIHomePage.aspx

\section{Notes}

Note 1. A potentially serious market-distortion on the supply side arises from the Renewable Energy Directive from 2010, which encourages the continued existence of 27 separate support policies for renewables and, given the target of a $20 \%$ overall share for RES in total energy consumption, means that some $35 \%$ of European electricity may be carved out of the market and cordoned off in a non-market enclosure.

Allowances to emit $\mathrm{CO} 2$ should be auctioned, not given free of charge, otherwise it will create a market failure in favour of the electricity industry.

Note 2. Some instruments do not create incentives for change, but only serve to generate extra revenue. There is no problem with that as long as they don't aggravate the overall efficiency of the system.

Note 3. The role of Electric Vehicles can be upgraded to independent wheels control and motion, leading to higher safety and less pollution (electric motors can break just by reversing the current, reducing the conventional breaks that uses small particles, like PM10, and other materials, like ferodo). This can be a boost for their massification.

\section{Copyrights}

Copyright for this article is retained by the author(s), with first publication rights granted to the journal.

This is an open-access article distributed under the terms and conditions of the Creative Commons Attribution license (http://creativecommons.org/licenses/by/4.0/). 